\title{
北海道十勝地方の鳥類
}

4. 農耕地の鳥類

$$
\text { 藤 巻 裕 蔵 }
$$

\section{Birds of Tokachi District, Hokkaido}

\section{Birds of Agricultural Land**}

\author{
Yuzo Fujimaki**
}

\begin{abstract}
Birds of an agricultural land were censused by the line-transect method at the Obihiro University Farm in Obihiro, Tokachi District, Hokkaido from 1976 to 1983. The study area is a mosaic of cultivated fields, pastures, shelterbelts of larch, forest islands of deciduous trees and farm facilities. A total of 76 species of birds was recorded by censuses of 92 times during the study. The number of species was 19 to 23 from January to March, then increased to 39 to 40 by recruitment of summer visitors. After August it decreased as summer visitors left the study area. Seasonal change in the number of birds for all species was similar to that of the number of species except in September and October, in which more birds of Passer montanus and Carduelis sinica were counted than in other months. In breeding season main species included Passer montanus around farm facilities, Emberiza spodocephala and Anthus hodgsoni at forest island, Saxicola torquata and Emberiza aureola in pasture, and so on. During winter Passer montanus and parid birds dominated. Avifauna at agricultural land was characterized by mixed one of both forest and grassland birds.
\end{abstract}

\section{は じめに}

十勝地方の農耕地は主に畑と草地（採草地, 放牧地）で, その中にカラマッなどの防風林や カシワ，ヤチハンノキなどからなる小面積の林が残っていて，これらがモザイク状になってい る。このような環境では草原性, 森林性両方の鳥類が生息し, それらの生活空間が重複するた めに草原または森林のどちらともつかない，これらが混った鳥相が見られる。この報告ではこ のような例の一つとして，带広市郊外の農耕地で調査した結果を報告する。

\section{調查地と調查方法}

調査地は帯広市郊外にある帯広畜産大学附属農場 $\left(42^{\circ} 52^{\prime} \mathrm{N}, 143^{\circ} 11^{\prime} \mathrm{E}\right.$, 標高 $\left.79 \mathrm{~m}\right)$ とそれに 隣接する農耕地, 林である。調查地の面積はおよそ 100 ha で, 畑, 牧草地, 放牧地, 未利用

\footnotetext{
Recieved 6 February 1984

* Contribution from the Laboratory of Wildlife Resource Ecology, Obihiro University of Agriculture and Veterinary Medicine, No. 39.

** Laboratory of Wildlife Resource Ecology, Obihiro University of Agriculture and Veterinary Medicine, Inada, Obihiro 080, Japan
} 


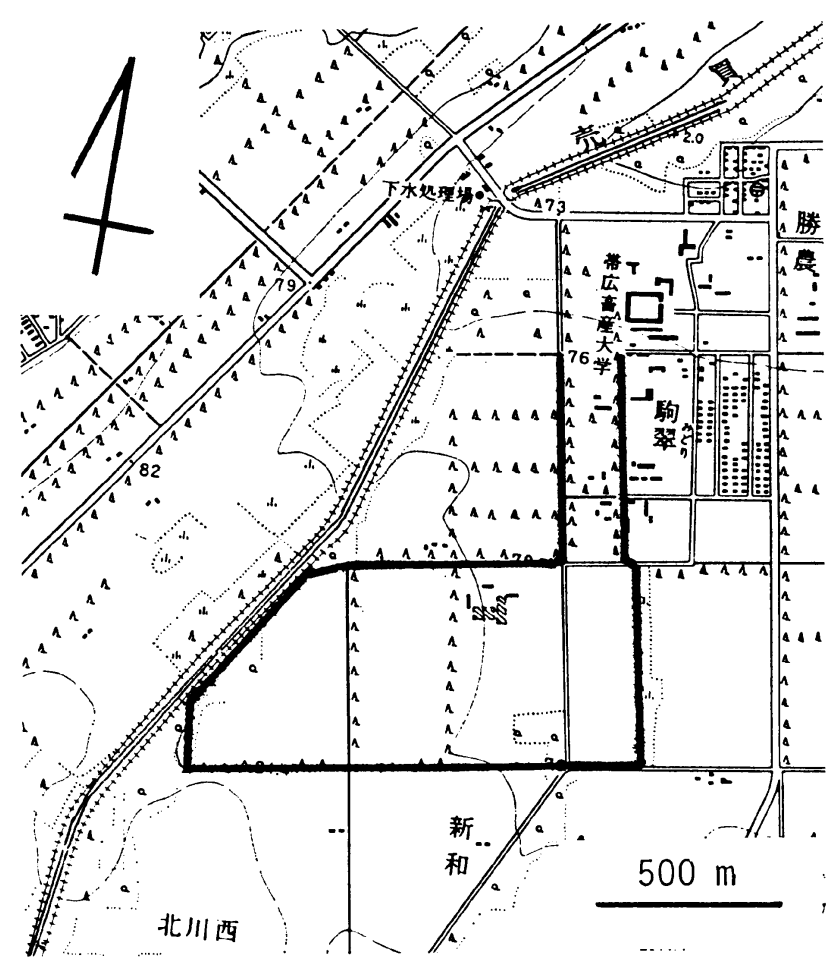

Fig. 1. Map showing census route in the study area.

の雑草地からなる。その中にカシワ，ヤチハンノキ，ヤチダモを主要種とする面積 1 ～ 2 ha $の$ 林やカラマツ防風林があり, 調査地西端の売買川沿いはヤナギ類, ドロノキ, ヤチハンノキ, シラカンバからなる林帯となっている。なお，この調査地は前報（藤巻 1981b）の調査地の方 形区 F-18, 19, G-18, 19 に含ま机る。調査地内を一周するように $4 \mathrm{~km}$ の調查路を設けた。 調査路の $12 \%$ は林の中を通り，60\% は防風林や林に接している。この注か調查路沿いに厩 舎や堆肥置場がある。

調査時期は 1976 年 4 月から 1977 年 12 月までで, このほか 1978，1980 1983 年に補 足調查を行った。各月の調査回数は 5 11 回, 全部で 92 回である。調査期間中畑の作物が デントコーンや牧草など相互に変ることがあったが，そのほかに環境に大きな変化はなかった。

調査地内の付属農場で記録された平均気温（1979 1982 年）は 8 月に最高で $19.1^{\circ} \mathrm{C}$, 最低 は 2 月で $-10.3^{\circ} \mathrm{C}$ で, 年平均気温は $5.3^{\circ} \mathrm{C}$ であった。積雪期間は 12 月下旬から 3 月中旬 までであるが，積雪は少なく 20 30 cm であった。

調査は, 調査路を時速 $2 \sim 2.5 \mathrm{~km}$ で歩きながらその左右各 $25 \mathrm{~m}$, 計 $50 \mathrm{~m}$ の観察帯内に出 現する鳥の種と個体数を記録した。なお観察帯に入らなくても近くに出現した場合には種だけ を記録した。 
北海道十勝地方の鳥類

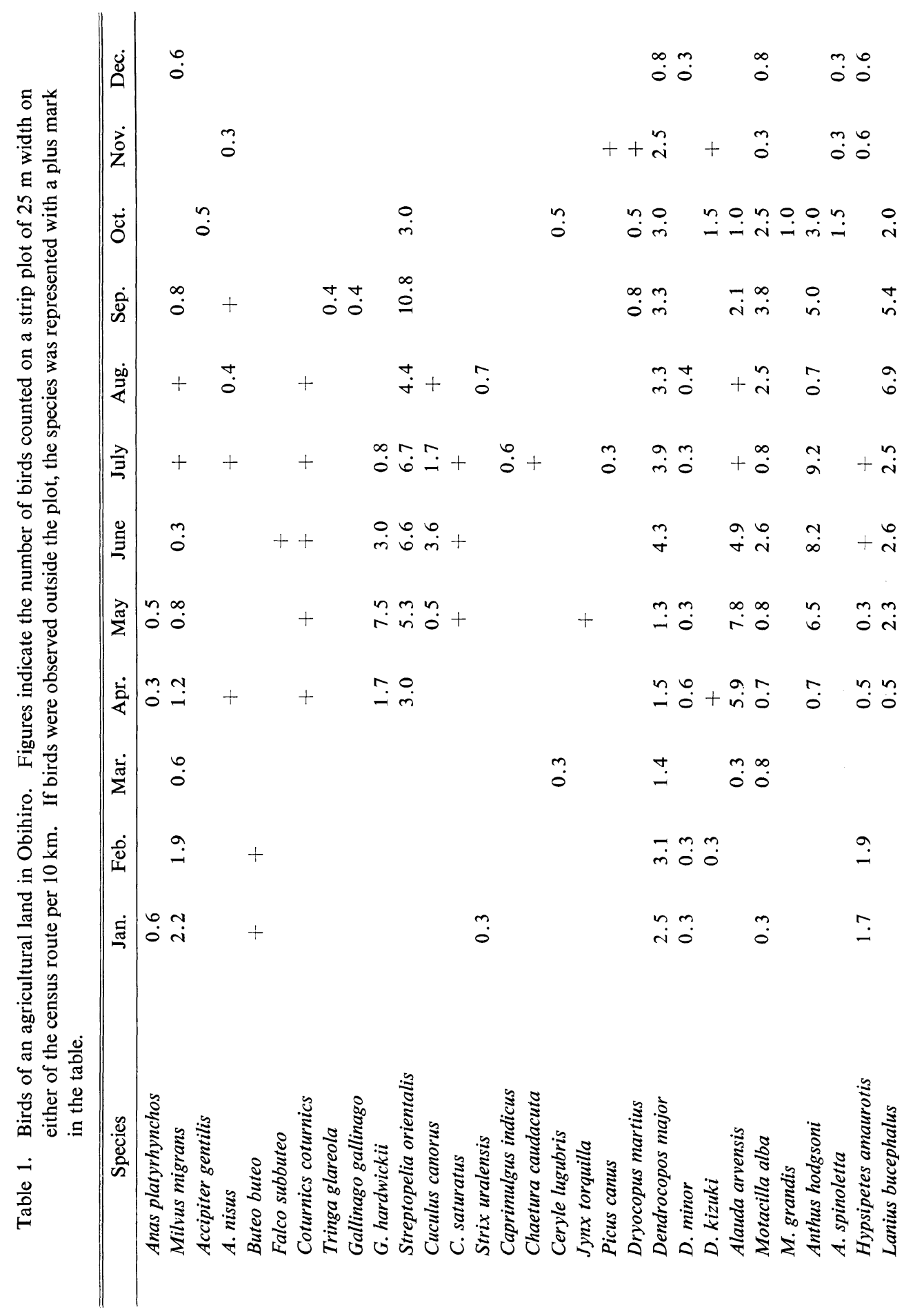




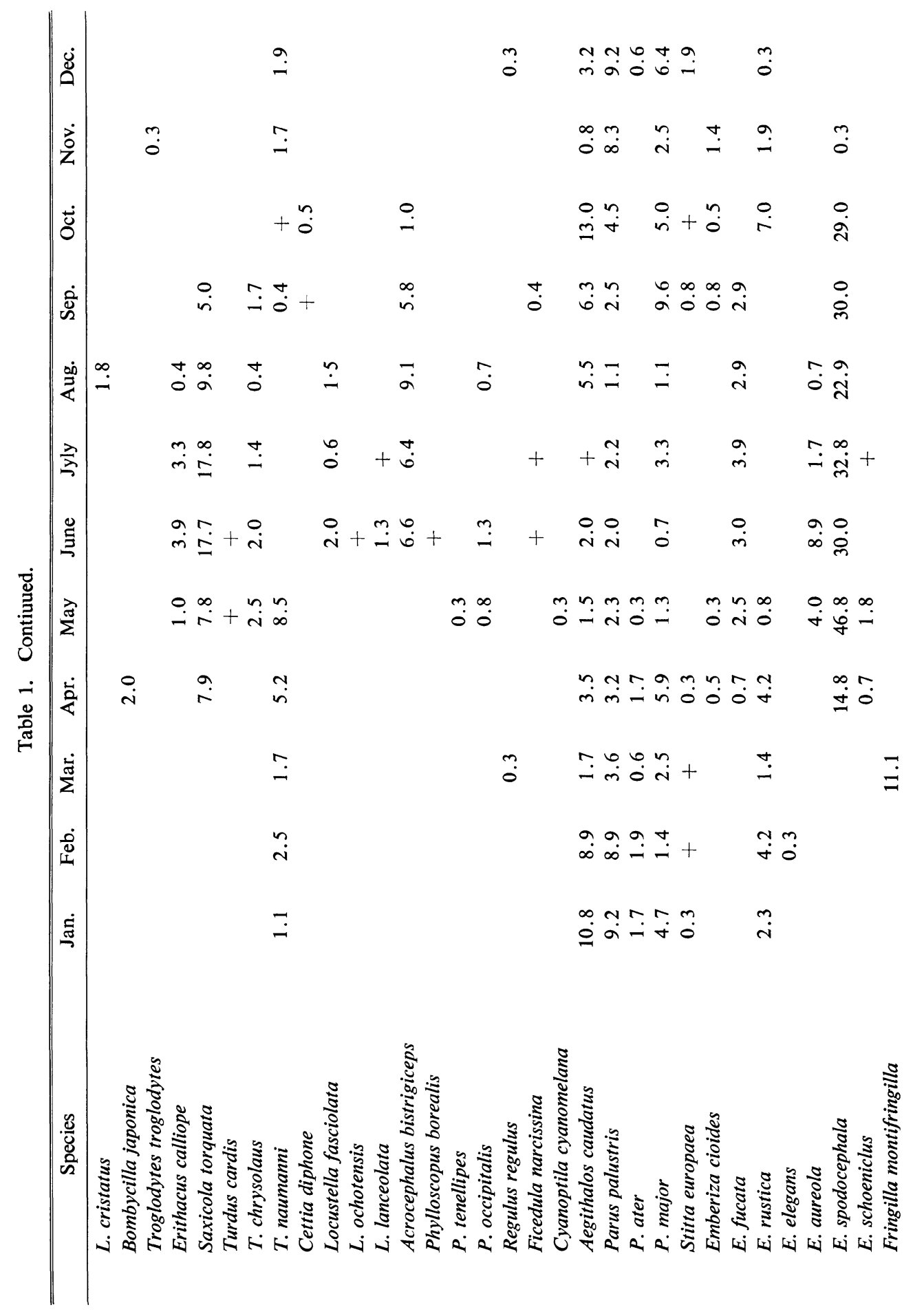




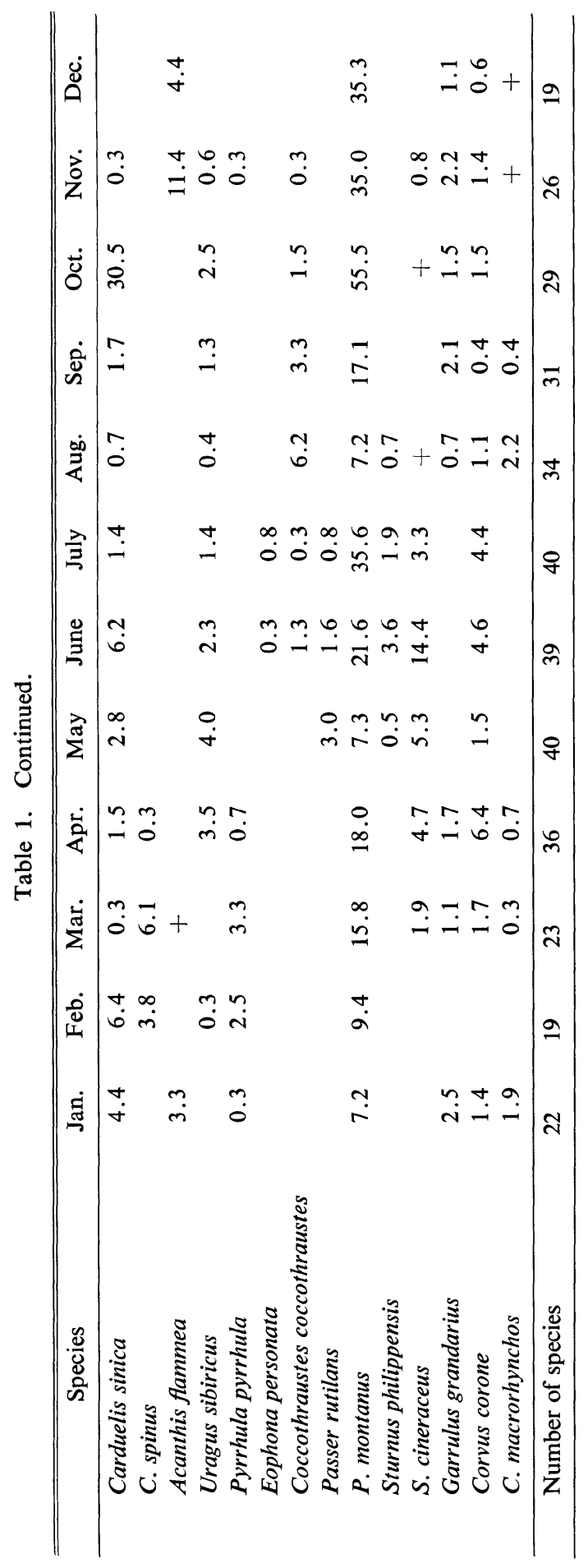




\section{結果}

調査結果を Table 1 に示す。調査の際観察帯内には出現しなかったが，近くにいて調査地内 に生息すると考えられる種を十印で示してある。

1 2 月は留鳥と冬鳥が見られた。留鳥としてはトビ，アカゲラ，コアカゲラ，ヒヨドリ， エナガ, ハシブトガラ, シジュウカラ, スズメなどが, 冬鳥としてッグミ, カシラダカ, ウソ などが普通であった。これらのうちトビは農場上を飛翔中のもの，スズメは厩舎周辺に生息し ているものであるほかは，林やカラマッ防風林で見られた。3 月には中〜下旬にヒバリ，ムク ドリが現れ始め, 留鳥や冬鳥に加わった。しかしこの期間の種数は 19〜23であった。4月に はいるとオオジシギ, キジバト，ビンズイ，モズ，ノビタキ，ホオアカ，アオジ，ベニマシュ などの夏鳥が渡来し，36 種に増えた。5 月にはさらにカッコウ、ッッドリ，ノゴマ，アカハ ラ，七ンダイムシクイ，シマアオジ，コムクドリなどが加わり，5月末から 6 月上旬にかけて エゾセンニュウ，コヨシキリも加わって，5７ 月の種数は 39〜40 種ともっとも多くなった。 夏鳥のらちクロツグミ，メボソムシクイ，エゾムシクイ，オオルリは渡りの途中に一時飛来し たもので，ごく短期間見られただけである。なお主要な夏鳥の初認日を Table 2 に示す。これ には今回の線状調査以外に得た記録も用いた。一方冬鳥の多くは 4 月中旬頃までに渡去するが, ッグミとカシラダカは 5 月中頃まで見られた。

8 月にはオオジシギやカッコウなど一部の夏鳥が見られなくなり始め，また生息していても 目につきにくくなって，種数は減少した。9１0 月には汪とんどの夏鳥が渡去する一方，この 時期から 11 月にかけて冬鳥やクマゲラ, コゲラ, ミソサザイ, カケスなど夏の間山地の森林

Table 2. First sight records of summer visitors for the year in the study area.

\begin{tabular}{lcccccccc}
\hline \hline \multicolumn{1}{c}{ Species } & 1976 & 1977 & 1978 & 1979 & 1980 & 1981 & 1982 & 1983 \\
\hline Gallinago hardwickii & Apr. 26 & Apr. 17 & Apr. 23 & Apr. 18 & Apr. 20 & Apr. 24 & Apr. 19 & Apr. 20 \\
Streptopelia orientalis & - & Mar. 28 & Mar. 23 & - & - & Mar. 24 & - & - \\
Cuculus canorus & May 24 & May 23 & May 21 & May 29 & May 26 & May 21 & May 19 & May 20 \\
C. saturatus & May 9 & May 9 & - & - & May 7 & May 13 & May 12 & May 6 \\
Jynx torquilla & Apr. 27 & - & Apr. 29 & Apr. 25 & - & Apr. 27 & - & - \\
Alauda arvensis & - & Mar. 28 & Mar. 25 & - & Mar. 28 & Mar. 23 & Mar. 28 & Apr. 1 \\
Anthus hodgsoni & Apr. 24 & Apr. 22 & - & Apr. 28 & Apr. 26 & Apr. 29 & Apr. 27 & Apr. 23 \\
Lanius bucephalus & - & Apr. 13 & Apr. 19 & - & - & - & - & - \\
Erithacus calliope & - & May 12 & May 20 & & May 24 & May 15 & - & - \\
Saxicola torquata & Apr. 14 & Apr. 13 & Apr. 14 & - & Apr. 15 & - & Apr. 13 & Apr. 11 \\
Turdus crysolaus & - & Apr. 26 & Apr. 23 & Apr. 29 & Apr. 22 & Apr. 28 & Apr. 28 & Apr. 25 \\
Locustella fasciolata & Jun. 3 & May 30 & - & Jun. 5 & May 29 & May 24 & - & - \\
L. lanceolata & Jun. 3 & Jun. 4 & - & - & Jun. 3 & - & - & - \\
Acrocephalus bistrigiceps & Jun. 3 & May 31 & May 29 & May 31 & - & & & \\
Emberiza fucata & Apr. 28 & Apr. 22 & Apr. 18 & Apr. 25 & - & - & Apr. 25 & \\
E. auroela & May 13 & May 12 & - & May 12 & May 14 & May 13 & May 11 & - \\
E. spodecephala & Apr. 17 & Apr. 13 & Apr. 18 & - & Apr. 14 & - & - & Apr. 15 \\
Uragus sibiricus & Apr. 13 & Apr. 13 & - & - & Apr. 18 & Apr. 4 & Apr. 3 & Apr. 2 \\
Passer rutilans & May 1 & Apr. 30 & Apr. 23 & Apr. 30 & Apr. 23 & Apr. 29 & Apr. 28 & Apr. 23 \\
\hline
\end{tabular}

-: unknown 


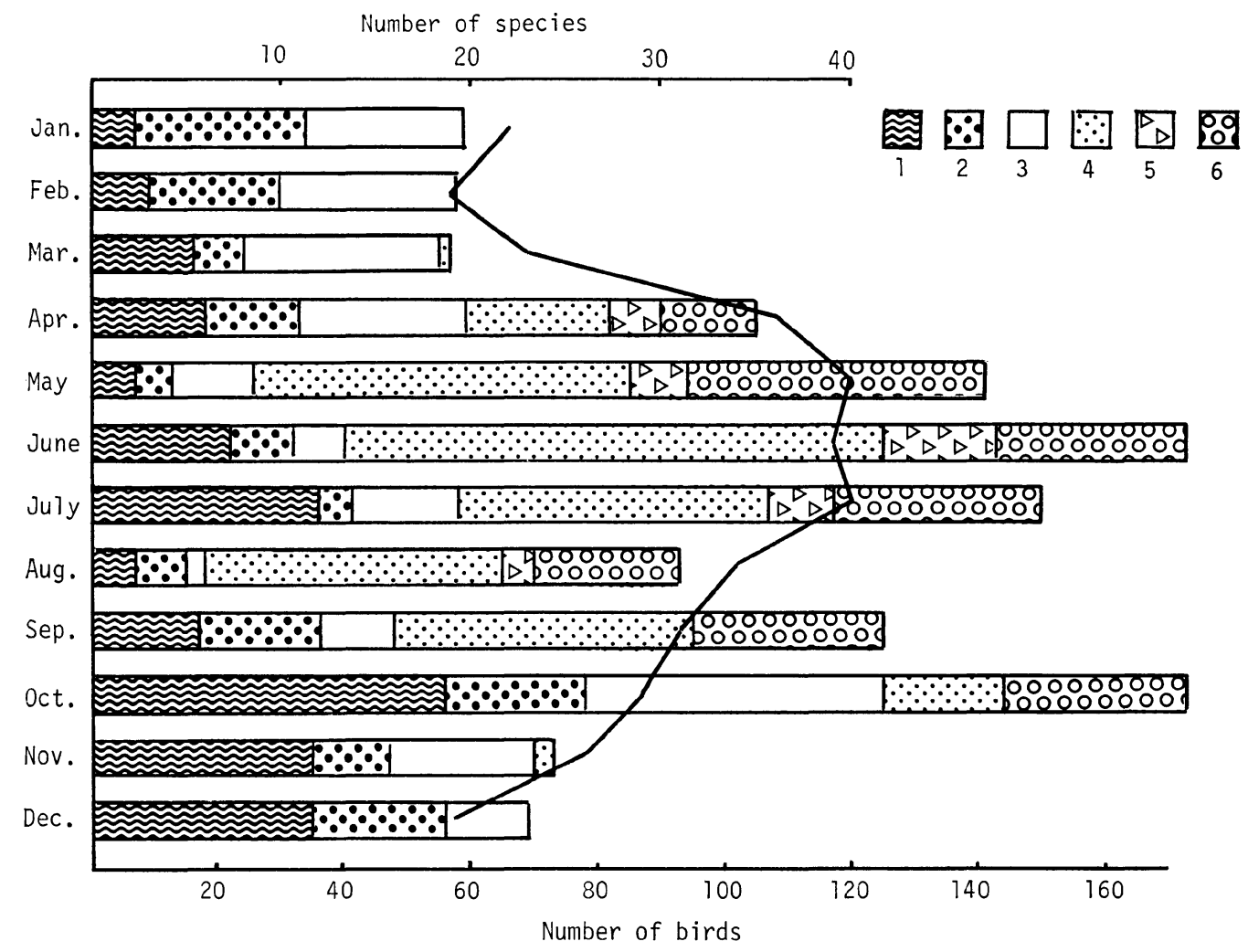

Fig. 2. Seasonal changes in number of species and birds for all species, and species composition. 1. Passer montanus, 2. Aegithalos caudatus, Parus palustris, P. ater, P. major and Sitta europaea, 3. winter visitor, transient and other residents, 4. summer visitor except Saxicola torquata and Emberiza spodocephala, 5. Saxicola torquata, 6. Emberiza spodocephala.

に生息していた種, タカブシギ, タシギ, タヒバリなどの旅鳥が観察された。しかし種数は夏 に比べて少なく，26〜31 種であった。12 月にはほとんど留鳥と冬鳥となり, 種数は再び 1 2 月と同程度となった。カワラヒワやベニマシコは一般に夏鳥であるが, 冬にも前者は20 30 羽 の群で, 後者は少数が見られることがあった。また冬鳥の渡来状況は年によって異なっていた。 帯広市周辺で見られるレンジャク類ではキレンジャクが普通であるが，1982 年にはヒレンジ ヤクが割合多く，この年の 4 月に調査地内の林で群が見られた。べニヒりは 1977/78, 1982/83 年の冬に多かった。

全種の観察個体数の季節変化は，一部の月を除くと種数の変化と同じ様な 傾 向を示した (Fig. 2)。各月の個体数の内訳を見ると，4 月から夏鳥の渡来とともに個体数が増加した。6月 中旬をすぎると, 巣立った幼鳥が目立つようになり, 種数に大きな変化がなくても個体数が変 化した。とくに道路沿いの牧柵ではノビタキ, 嘅舎周辺ではスズメ, 放牧地では群となったム クドリが多かった。8 月には種数の減少とスズメが主としてデントコーン畑に移動したため調 
Table 3. Main species and their relative dominance in the study area. Figures in parentheses indicate relative dominance percentage.

\begin{tabular}{ll}
\hline \hline \multicolumn{1}{c}{ May to July } & December to February (of next year) \\
\hline Emberiza spodocephala $(23.6)$ & Passer montanus $(28.0)$ \\
Passer montanus $(13.9)$ & Parus palustris $(14.7)$ \\
Saxicola torquata $(9.3)$ & Aegithalos caudatus (12.3) \\
Anthus hodgsoni $(5.1)$ & Parus major $(6.7)$ \\
Sturnus cineraceus $(5.0)$ & Carduelis sinica $(5.8)$ \\
Streptopelia orientalis $(4.0)$ & Acanthis flammea $(4.1)$ \\
Emberiza aureola $(3.1)$ & Emberiza rustica $(3.7)$ \\
Acrocephalus bistrigiceps $(2.8)$ & Dendrocopos major (3.4) \\
Gallinago hardwickii $(2.4)$ & Milvus migrans $(2.5)$ \\
Covrus corone $(2.3)$ & Hypsipetes amaurotis $(2.3)$ \\
Carduelis sinica $(2.2)$ & Parus ater $(2.3)$ \\
Dendrocopos major $(2.0)$ & Carduelis spinus $(2.0)$ \\
Emberiza fucata $(2.0)$ & \\
\hline
\end{tabular}

查路沿いで少なくなり，全体の個体数が減少した。9 月にはスズメが再び厩舎付近に集まり始 め，カラ類の群が目立つようになって，個体数が増加した。また 10 月には畑の作物の収穫後 スズメが厩舎周辺に集中したのと， カワラヒワ(10 月のカワラヒワは標識調査によると浪と んどオオカワラヒワであったので，Fig. 2 では夏鳥から除いてある）が群で出現したため個体 数が増えた。このように, 少数の種の個体数の増減により, 全体の個体数と種数の变化の傾向 が必ずしも一致しなかった。

繁殖期と非繁殖期の鳥相の特徵を示すため, それぞれ $5 \sim 7$ 月, 12 月〜翌年の 2 月の結果 をまとめて相対優占度を算出し $2 \%$ 以上の種を Table 3 に示す。繁殖期の優占上位種はノビ タキ，アオジ，スズメで，それぞれ主として草原，林，厩舎付近で見られ，いろいろの環境の 鳥類が含まれる。その他 Table 3 にあげた鳥類では森林性より草原性の鳥類が多くなっている。 非繁殖期にはスズメが最も優占し，ついでカラ類といった森林性鳥類が多かった。スズメを除 くと,これらの多くは林や防風林沿いに出現した。

\section{考察}

今回の調査では 76 種が記録されたが, この種数はこれまで十勝地方で今回と同様の方法で 行われた調査結果（藤巻, 1980, 1981a) と比べると多い。これは, 今回の調查回数が多く, 普 通は出現頻度の低い種も記録されたためであろら。そこで農耕地の鳥相の特徵を述べるのに相 対優占度が上位にある種をとりあげて検討することにする。

夏鳥の渡来は 3 月下旬に始まったがこの時期には少なく，4 月にはいると本格的となり，6 月上旬までには終る。そして 8 月には渡去する種がいるので，夏の鳥相をみるのに 5 7 月を とりあげた。優占種はまず人家周辺を主な生息場所とするスズメで，それに森林性と草原性両 方の鳥類であった。新得の農耕地でもカラマッ防風林や小さな林があって, 主要種は今回の調 査地と汪とんど共通して扣り（藤巻 1980), 両者の類似度 (Whittacker 1952) は0.59であっ た。ただ森林性鳥類が生息するといっても，それらはキジバト，ビンズイ，アオジのように主 として林縁を好んだり, 開けた環境で採䬲する種であった。新得山の落葉広葉樹林の鳥相を見 
ると(藤巻 1980), コルリ，七ンダイムシクイ，キビタキ，イカルが主要種に含まれるが，今 回の調査地では林があっても小面積のため, これらが生息しないかいても非常に少なく, 両者 の類似度は 0.35 と低かった。な技今のところ北海道の草原の鳥類について同様の方法で調查 したものがないので, 今回の結果との比較はできない。

秋から冬にかけては夏鳥の渡去, 旅鳥の通過, 冬鳥の渡来と種構成が大きく変化する時期で ある。その後 12 月〜装年の 2 月には種構成が安定する。そこで冬の鳥相をみるのにこの期 間をとりあげた。スズメは繁殖期と同様に優占種であった。他の優占種は夏と異なり，森林性 の留鳥が多かった。そのため新得山の落葉広葉樹林の鳥類群集との類似度は $0.42 て ゙$, 夏より 高かった。草原性の種は一部の冬鳥を除くといなくなった。北海道の農耕地は森林に比べると 冬期間の積雪の存在により鳥類の生息環境としては著しく不適となる。ただ十勝地方の積雪は 北海道の日本海側に比べると少なく，普通は夏鳥とされている種がわずかに残留することがあ る。今回も冬にカワラヒワとベニマシコが見られた。

農耕地は建物, 畑, 牧草地, 防風林, 小面積の林がモザイク状となった環境で, ここで見ら れる鳥類群集も環境のこのような特徵を反映して人家周辺の鳥類, 一部の草原性, 森林性鳥類 が混った独特なものとなる。をた種数も森林だけや草原だけの環境におけるよりも多くなる。 農耕地の環境は人工的な単純化されたものであるが，その中に防風林や林があることにより， 鳥類の生息環境としては多様になる。とくにこの効果は冬に著るしいといえる。

\section{摘要}

1. 带広市郊外にある帯広畜産大学付属農場で, 1976 年 4 月 1983 年 12 月に調査を行い農耕地の鳥 類群集を明らかにした。

2. 種数は 1 3 月には 19 23 種， 4 月から夏鳥の渡来とともに増加し，5７ 月には 39４0 となり， その後は減少した。

3. 全体の個体数も，一部の月を除いて種数と同様の季節变化を示した。

4. 繁殖期の主要種はスズメ, アオジ，ノビタキなど, 人家周辺の鳥, 森林性と草原性の鳥類であった。

5. 冬の主要種はスズメのほか, 森林性の留鳥であった。

\section{引用 文 献}

藤巻裕蔵 1980. 北海道十勝地方の鳥類. 1. 新得山とその付近の鳥類. 山階鳥研報 12: 40-52.

藤巻裕蔵 1981a. 同上 2. 帯広市の都心部とその周囲の鳥類. 山階鳥研報 13: 37-49.

藤巻裕蔵 1981b. 同上 3. 帯広市における植被と鳥類の関係。山階鳥研報 13: 50-60.

Whittaker, R. H. 1952. A study of summer foliage insect communities in the Great Smoky Mountain. Ecol. Monog. 22 : 1-44.

藤巻裕蔵：帯広音産大学, 野生動物管理学研究室. 干080 帯広市稲田町 